chosen specialty, must pass external independent evaluation tests on general terms. In particular, admission to the most technical and engineering specialties requires taking a math test. Re-learning math for some adults means to study math from scratch.

Due to the small duration of external independent evaluation in mathematics in our country and the recent introduction of compulsory testing for all students, regardless of the time of graduation, the issue of preparing adults for mathematics testing remains unresolved in the methodological literature, which is the purpose of the article.

The purpose of the article is to identify the main aspects of preparing adults for external independent evaluation in mathematics, taking into account their age characteristics.

The main aspects of preparing adults for taking external independent evaluation tests in mathematics, which include both psychological and mathematical training, are regarded in the article.

The research is based on the experience of preparing adults for past tests. According to the research a minimum program for entrants has been invented. This program contains a minimum set of formulas to learn by heart. The article presents an indicative plan on topics for the revision of a school mathematics course. The most of algebra and mathematical analysis points focus on graphs of functions and their analysis.

The indicative plan of geometry revision differs from school mathematics program. It presents only topics of themes. The plan will be presented in more details in future studies.

Key words methods of mathematics, external independent evaluation in mathematics, testing in math, preparing for EIT, course of school mathematics, applicant, adult training program, minimized training.

УДК 1.378 .796 .32

Володимир Борисенко Чернігівський національний технологічний університет ORCID ID 0000-0003-0840-6040

Юлія Козерук Національний університет «Чернігівський колегіум імені Т.Г.Шевченка ORCID ID 0000-0002-8777-1726

Тетяна Гриб

Сумський національний аграрний університет ORCID ID 0000-0001-8957-8244

Тетяна Клименченко

Сумський національний аграрний університет ORCID ID 0000-0002-7835-6432

DOI 10.24139/2312-5993/2019.08/189-198

\title{
РОЗВИТОК РУХОВИХ ЯКОСТЕЙ СТУДЕНТІВ ПІД ЧАС НАВЧАННЯ ВОЛЕЙБОЛУ В ПРОЦЕСІ ФІЗИЧНОГО ВИХОВАННЯ
}

Мета дослідження полягає у спробі систематизувати вправи загальної фізичної підготовки, що в комплексі слугуватимуть базою для навчання волейболу в прочесі фрізичного виховання. Даний комплекс можливо рекомендувати для студентів закладів вищої освіти у формі неформального та інформального 
навчання, що сприятиме вирішенню питання щодо зростаючих вимог до універсальної підготовки уволейболі

Для досягнення поставленої мети використано такі методи дослідження: аналіз, узагальнення наукової літератури з питань сутності базових понять професійної термінології, систематизація вправ для розвитку окремих рухових якостей у процесі загальної фрізичної підготовки.

Ключові слова: студенти, волейбол, фізичне виховання, рухові якості.

Постановка проблеми. Волейбол на сьогодні висуває високі вимоги до розвитку рухових якостей гравців та їх функціональних можливостей. Угрі безліч технічних прийомів раптових переміщень, стрибків, падінь, ударів (Борисенко, 2018; Волейбол, 2006; Носко, 2003). Це вимагає від студентів закладів вищої освіти (ЗВО) всебічного розвитку рухових якостей. Досконале опановування технікою гри можливо за наявності відповідного рівня розвитку рухових якостей, як загальної, так і спеціальної підготовленості (Козерук та Філоненко, 2016; Рибалко та ін., 2017). В ігровій діяльності у волейболі рухові якості тісно взаємопов'язані.

Загальна фізична підготовка $є$ і завжди буде базою для технічної та тактичної підготовки (Архипов, 2005). Тому поряд з удосконаленням технічної, тактичної та психологічної підготовки важливим завданням освітнього процесу $€$ підвищення загальної та спеціальної рухової підготовленості й поліпшення функціональних можливостей студентів.

Аналіз актуальних досліджень. Загальна фізична підготовка при навчанні волейболу охоплює широке коло вправ, що розвивають рухові якості в такому співвідношенні, яке необхідно саме в цьому виді спорту, що спрямовано на різнобічний фізичний розвиток, зміцнення здоров'я, коригування правильної постави, підвищення функціональних можливостей організму, розширення об'єму рухових навичок, розвиток рухових якостей (сили, швидкості, витривалості, спритності, гнучкості), підвищення ігрової, змагальної працездатності, стимулювання відновних процесів в організмі (Борисенко, 2018; Борисенко та ін., 2019; Носко, 2003; Рибалко та ін., 2017).

Засобами загальної фізичної підготовки є загальнорозвальні вправи, спрямовані на розвиток рухових якостей у процесі ходьби, бігу, стрибків, метань, а також вправи на різних снарядах, тренажерах, заняття іншими видами спорту (Архипов, 2005).

Періодично під загальнорозвивальні вправи виділяються окремі заняття. Питома вага загальнорозвивальних вправ у заняттях на окремих етапах і періодах освітнього процесу $є$ різною. Їх залежно від поставлених завдань можна включати в підготовчу частину заняття, основну й заключну.

Мета дослідження - систематизувати вправи загальної фізичної підготовки як бази для навчання волейболу в процесі фізичного виховання, що можливо рекомендувати для студентів 3ВО у формі неформального та інформального навчання. 
Методи дослідження: аналіз, узагальнення наукової літератури 3 питань сутності базових понять професійної термінології, систематизація вправ для розвитку окремих рухових якостей у процесі загальної фізичної підготовки.

Виклад матеріалу. Розвиток рухових якостей знаходиться в тісному взаємозв'язку та взаємній обумовленості. Розвиток одного з них певним чином впливає на розвиток інших. При цьому вплив може бути позитивним, нейтральним та негативним, наприклад, якщо більше уваги приділяти розвиткові сили, то втрачається гнучкість і рухливість у суглобах. Отже, питання про найбільш доцільний розвиток рухових якостей має велике значення. Оптимальний розвиток рухових якостей відбувається у процесі їх комплексного застосування (Борисенко, 2018; Рибалко та ін., 2017).

Сила - це вміння долати зовнішній опір або протидіяти йому шляхом напруження м'язів та залежить від ряду факторів:

- фізіологічного стану м'язів;

- загального стану центральної нервової системи;

- швидкості хімічних змін у м'язовій тканині;

- вольового зусилля;

- ступеня втоми м'язів.

Сила у волейболі має велике значення, вона необхідна в стрибках, передачах і подачах, а також ударах по м'ячу. Від рівня розвитку сили залежить швидкість рухів, сила дає можливість кращих результатах розвитку швидкості.

Засобами розвитку сили є вправи, виконання яких тісно пов'язане $з$ подоланням опорів. У якості опору можуть бути використані:

- вага власного тіла та його частин (підтягування, присідання, згинання та розгинання рук в упорі лежачи та інше);

- зовнішні обтяження (гантелі, штанга та інше);

- опір предметів (еспандера, гуми) та партнера.

Найбільш ефективними вправами для розвитку сили є вправи 3 обтяженнями. Вони дуже зручні, тому що можна дозувати обсяг i інтенсивність навантаження, впливати як на окремі м'язи, так і на певні їх групи. Важливо обрати оптимальну вагу обтяження. Установлено, що при навантаженнях, рівних 35-40 \% від максимальної сили, заняття 3 початківцями приносять відчутний результат.

Обтяження бувають великі, середні та малі. Середньою вагою $є$ така вага, яку в одному з трьох підходів можна виконати вправу 8-10 разів. Повторне виконання вправи з граничними обтяженнями називається методом повторних зусиль. У практиці цей метод отримав широке поширення. Пояснюється це тим, що виконання загального обсягу роботи викликає в організмі посилений обмін речовин, а це призводить до збільшення м'язової маси й помірного розвитку сили. Метод повторних зусиль може бути рекомендований для занять із новачками. Після 
приблизно двомісячних занять із середніми обтяженнями зі збільшенням м'язової маси величину опору відповідно підвищують. Показником переходу до збільшення навантаження $€$ можливість виконання даної фізичної вправи більше ніж 12-14 разів.

Метод «під зав'язку» полягає в безперервному та багаторазовому повторенні вправ із середнім та великим навантаженням (40-60 \% від максимального). Багаторазове повторення силових вправ викликає посилену діяльність серцево-судинної системи. Після закінчення тільки однієї серії частота серцевих скорочень (чСС) збільшується до 160170 ударів на хвилину. До виконання наступної серії вправ можна приступати при частоті пульсу 80-90 ударів на хвилину. Практично таке зниження ЧСС відбувається при інтервалах відпочинку в межах 1,5-3 хв.

М'язова сила може бути максимально проявлена в конкретних фізичних вправах лише при дотриманні координації рухів (Борисенко, 2018). Тому поряд із розвитком сили за допомогою силових вправ, її слід розвивати в процесі виконання технічних прийомів або їх частин, застосовуючи пов'язаний метод. Наприклад, виконання нападаючого удару з посильним обтяженням на руках або ногах. Ця обставина являє спрямованість занять із силової підготовки волейболістів.

Для розвитку швидкісно-силових якостей застосовується також метод «неграничних зусиль» - вправи виконують з граничною швидкістю (3050 \% від максимальних).

На початковому етапі вправи з обтяженнями виконуються в повільному темпі, а надалі - швидко. Вправи на силу чергуються 3 вправами на розслаблення; після вправ з великими обтяженнями слідує відпочинок один-два дня, з невеликими - можна виконувати щодня.

Широко застосовується також метод колового тренування - вправи підбираються таким чином, щоб у роботу послідовно залучалися основні групи м'язів.

Приклади вправ для розвитку сили:

1. Жим штанги вагою 20-35 кг.

2. Ривок штанги вагою 15-20 кг.

3. Нахили зі штангою вагою 15-20 кг.

4. Присідання зі штангою вагою 30-50 кг.

5. Метання (штовхання) ваги (гирі, ядра, набивні м'ячі).

6. Вправи з гирею, гантелями, тощо (нахили, ривки, обертальні рухи).

7. Згинання-розгинання рук в опорі лежачи на пальцях.

8. Відштовхування від опори руками та ногами з положення в упорі лежачи.

9. Пересування на руках з упору лежачи (без допомоги ніг) по колу.

10. Пересування в упорі сидячи (руки ззаду), перебираючи руками, ногами. 
11. Стрибкові вправи (підскоки, стрибки на одній, на двох ногах).

12. Перенесення партнера кроком, бігом.

13. Присідання з партнером на плечах.

14. Вправи з опором - утримання рук із різних вихідних положень.

15. Вправи з канатами.

16. Метання тенісного м'яча, зберігаючи структуру нападаючого удару.

17. Кидки набивних м'ячів (1-3 кг) через сітку.

Швидкість у волейболі - це комплекс функціональних якостей спортсмена, які виявляються: у швидкості простих і складних реакцій у відповідь на один або кілька подразників; у швидкості виконання прийомів техніки гри; у швидкості переміщення гравця на майданчику.

Основним засобом розвитку швидкості рухів вважається повторне виконання рухів з граничною швидкістю. Кількість використовуваних вправ має бути незначною, але вони необхідні на кожному занятті. Важливе значення для розвитку швидкості рухової реакції мають вправи на виконання завдань за несподіваним сигналом.

Вправи на розвиток швидкості мають бути різноманітними та охоплювати різні групи м'язів. Вони повинні сприяти вдосконаленню регуляторної діяльності центральної нервової системи, підвищенню координаційних здібностей студентів.

Дослідження показали, що такі вправи стають ефективнішими, коли їх використовують у відповідному співвідношенні зі стрибковими. Для розвитку швидкості необхідно насамперед використовувати швидкісносилові вправи.

Адже в переважній більшості видів спорту швидкість пов'язана 3 вибуховою м'язовою силою. Прикладом таких вправ можуть бути стрибки, стрибкові вправи з обтяженням (набивні м'ячі, обтяжувачі).

Для розвитку швидкості в студентів вправи добирають диференційовано, а саме: вправи на розвиток швидкості реакції, вправи на розвиток частоти рухів, вправи на розвиток швидкості переміщення. Швидкість необхідно нарощувати поступово й збільшувати амплітуду рухів, обов'язково доводячи їі до максимальної величини. Вправи виконують у полегшених умовах (біг під гору, з використанням лідера тощо) або спочатку в ускладнених умовах, а потім у звичайних.

Вправи будуть ефективними тоді, коли студент може контролювати й точно оцінювати швидкість рухів. Тренувальні заняття організовуються так, щоб вправам на розвиток швидкості не передувала будь-яка робота, що втомлює студентів.

Приклад вправ для розвитку швидкості:

1. Ривки та прискорення по зоровому сигналу з різних вихідних положень. 
2. Стрибки через скакалку з максимальною частотою обертання.

3. Ривки з миттєвою зупинкою та різкою зміною напрямів руху.

4. Швидке переміщення вздовж сітки 3 виконанням кидків набивними м'ячами двома руками зверху через сітку і в зони нападу.

5. Швидке переміщення до сітки з однієї зони в другу з подальшим відбіганням (спиною вперед) в іншу ігрову зону при виконанні імітації нападаючого удару тенісними м'ячами.

6. Швидке переключення від одних дій до інших, різних за характером.

Витривалість визначають як здатність людини протягом тривалого часу виконувати безперервну динамічну роботу великої або помірної потужності з характерним функціонуванням провідних систем організму.

Витривалість - важлива якість для гравця у волейбол, вона виявляється в здібності боротися зі стомленням, яке наступає після великих навантажень. Розвиток витривалості дає змогу підвищити працездатність гравця.

Для розвитку витривалості використовують циклічні вправи помірної інтенсивності у відносно рівномірному темпі, як наприклад: біг по пересіченій місцевості, який чергується з ходьбою, ходьба на лижах, походи в горах, легкоатлетичний біг на середні й довгі дистанції, їзда на велосипеді, весловий спорт, плавання тощо.

Сучасні дослідження свідчать, що особливу увагу необхідно приділяти розвитку витривалості у студентів, починаючи з першого курсу. 3 віком витривалість поступово збільшується, але нерівномірно. Вправи для розвитку витривалості, як правило, проводять наприкінці основної частини заняття.

Приклад вправ для розвитку загальної витривалості:

1. Ходьба на лижах.

2. Кросовий біг, біг середньої інтенсивності, біг відрізками.

3. Плавання.

4. Гра в баскетбол та інші рухливі ігри..

5. Проведення ігор з більшою, ніж передбачено правилами змагань, кількістю партій.

6. Проведення ігор на час.

7. Під час пауз між партіями в грі (протягом 5-10 хв.) виконати інтенсивні фізичні вправи - стрибки, ривки та інше.

8. Почати гру у швидкому темпі й також закінчувати їі, попри сильне стомлення.

Спритність проявляється в здібностях гравця швидко й сміливо виконувати складні за координацією дії, правильно розв'язувати різні рухливі завдання, швидко перебудовувати свою діяльність відповідно до обставин. Спритність багато в чому залежить від сили, швидкості, витривалості, бо швидке стомлення, що виникає при недостатньому рівні 
розвитку даних якостей, призводить до різкого порушення координації рухів. Для розвитку спритності доцільно систематично використовувати нові, несподівані для студентів вправи.

Розвиваючи спритність у гравців, швидко переключатися з однієї дії на іншу, використовують рухливі та спортивні ігри, біг із перешкодами, акробатичні вправи в різноманітному поєднанні, естафети, стрибки в довжину або глибину, жонглювання м'ячами, стрибки на батуті 3 додатковими рухами рук, вправи на рівновагу та інше.

Визначаючи кількість вправ, необхідно враховувати, що вони, крім фізичних зусиль, спричиняють і значне нервове напруження. Вправи на спритність проводяться на початку основної частини заняття.

Приклад вправ для розвитку спритності:

1. Спортивні та рухливі ігри.

2. Естафети, естафети з передачами м'яча в русі (передачі знизу, зверху).

3. Гімнастичні стрибки, перекиди, падіння, перевороти, перекати.

4. Стрибки з підкидного містка.

5. Приземлення на руки з положення стоячи.

6. Приземлення на руки з положення стоячи спиною вперед із поворотом.

Гнучкість (рухливість у суглобах) - це здібність гравця виконувати ігрові рухи з великою амплітудою. Гнучкість деякою мірою впливає на швидкість і точність ігрових рухів. Спеціальний розвиток гнучкості - складова частина тренувального процесу, але слід пам'ятати, що надмірна рухливість стає перешкодою для технічно правильного виконання деяких прийомів гри.

Для розвитку гнучкості використовуються вправи зі збільшеною амплітудою руху (вправи на розтягування), що виконуються пружно й невеликими серіями; амплітуда рухів збільшується від серії до серії. Особливу увагу слід звертати на розвиток рухливості тазостегнового і плечового суглобів, а так само в суглобах кистей рук і гомілковостопному. Вправи на гнучкість можна давати у вигляді самостійних завдань.

Приклад вправ для розвитку гнучкості:

1. Нахили вперед, у сторони, назад. Ці вправи можна виконувати 3 партнером.

2. Пружинні випади вперед і в сторони.

3. Колові рухи тазом.

4. Махи руками і ногами з невеликими обтяженнями.

5. Імітація різних вправ з великою амплітудою рухів.

Висновки. Ураховуючи зростаючі вимоги до універсальної підготовки у волейболі, актуальним $€$ питання про важливість загальної фізичної підготовки як бази для навчання волейболу в процесі фізичного виховання студентів ЗВО. 
У результаті роботи систематизовані справи для розвитку окремих рухових якостей у комплекси вправ, що можна рекомендувати у формі неформального та інформального навчання.

Перспективами подальших досліджень вважаємо систематизацію вправ спеціальної рухової підготовки студентів 3 ВО під час навчання волейболу в процесі фізичного виховання.

\section{ЛІТЕРАТУРА}

Архипов, О. А. (2005). Новітні технології навчання у фізичному вихованні студентства. IX международный научный конгресс «Олимпийский спорт и спорт для всех», (сc. 102-103). Киев: Олимпийская литература (Arkhypov, O. А. (2005). Newest technologies of teaching in physical education of students. Proceedings of the IX International Scientific Congress "Olympic sports and sports for all", (pp. 102-103). Kyiv: Olympic literature).

Борисенко, В. В. (2018). Теоретичні аспекти розвитку координаційних якостей. Матеріали наукових дискусій кафедри педагогіки, психології і методики фізичного виховання, (сс. 33-35). Чернігів: НУ «ЧК» імені Т.Г. Шевченка (Borysenko, V. V. (2018). Theoretical aspects of coordination qualities development. Materials of scientific discussions of the Department of Pedagogy, Psychology and M ethods of Physical Education, (cc. 33-35). Chernihiv).

Борисенко, В., Козерук, К., Денисовець, А., Козерук, Ю. (2019). Методи контролю в прочесі занять фозичними вправами. Педагогічні науки: теорія, історія, інноваційні технології, 5 (89), 23-29 (Borysenko, V., Kozeruk, K., Denysovets, A., Kozeruk, Yu. (2019). Control methods in the process of physical training. Pedagogical sciences: theory, history, innovative technologies, 5 (89), 23-29).

Беляев, А. В., Савин, М. В. (ред.) (2006). Волейбол. М.: Физкультура и спорт (Beliaiev, А. V., Savin, M. V. (Eds.) (2006). Volleyball. M.: Physical education and sport).

Козерук, Ю. В., Філоненко, О. А. (2016). Актуальні питання непрофесійної фізкультурної освіти на шляху модернізації змісту і форм фізичного виховання. Науковий часопис Національного педагогічного університету імені М.П. Дрогоманова. Серія № 15. «Науково-педагогічні проблеми фрізичної культури, Вип. 3 К 1 (70) 16, 45-48 (Kozeruk, Yu. V., Filonenko, O. A. (2016). Topical Issues of Non-Professional Physical Education on the Path of Modernizing Content and Forms of Physical Education. Scientific journal of the National Pedagogical University named after M. P. Drogomanov. Series № 15. "Scientific and pedagogical problems of physical culture", Issue of ZK 1 (70) 16, 45-48).

Королінська, С. В., Зелененко, Н. О. (2018). Основи техніко-тактичної підготовки у волейболі студентів вищих навчальних закладів. Харків: Національний фармацевтичний університет (Korolinska, S. V., Zelenenko, N. O. (2018). Basics of technical-tactical training in volleyball for students of higher educational establishments. Kharkiv).

Носко, М. О. (2003). Теоретичні та методичні основи формування рухової функції у молоді під час занять фізичною культурою та спортом (автореф. дис. д-ра пед. наук: 13.00.09). Київ (Nosko, M. О. (2003). Theoretical and methodological foundations of the formation of motor function in youth during physical education and sports (DSc thesis abstract). Kyiv).

Носко, М. О., Архіпов, О. А., Жула, В. П. (2015). Волейбол у фізичному вихованні студентів. Київ: «МП Леся» (Nosko, М. O., Arkhipov, O. A., Zhula, V. P. (2015). Volleyball in physical education of students. Kyiv: "MP Lesia". 
Рибалко, П. Ф., Гриб, Т. О., Клименченко, Т. Г. (2017). Проблеми і шляхи підвищення ефективності фізичного виховання у вищому навчальному закладі нефізкультурного профілю. Фізична культура, спорт та здоров'я начії, Buп. 1, 217-221 (Rybalko, P. F., Hryb, T. O., Klymchenko, T. H. (2017). Problems and ways of improving the efficiency of physical education in a non-physical education higher education institution. Physical Education, Sports and Health of the Nation, Iss. 1, 217-221).

Рибалко, П. Ф., Матлаш, В. А., Андрєєва, І. А. (2016). Особливості проведення секційних занять 3 юнаками-волейболістами 18-20 років. Вісник Чернігівського національного педагогічного університету імені Т.Г.Шевченка, Вип. 140 (Rybalko, P. F., Matlash, V. A., Andrieieva, I. A. (2016). Features of section sessions with youth volleyball players 18-20 years. Bulletin of Chernihiv Taras Shevchenko National Pedagogical University, Vol. 140).

\section{PEЗЮME}

Борисенко Владимир, Козерук Юлия, Татьяна Гриб, Татьяна Клименченко. Развитие двигательных качеств студентов во время обучения волейбола в процессе физического воспитания.

Цель исследования заключается в попытке систематизировать упражнения общей физической подготовки, которые в комплексе будут служить базой для обучения волейболу в процессе физического воспитания. Данный комплекс можно рекомендовать для студентов учреждений высшего образования в форме неформального и информального обучения, что будет способствовать решению вопроса о растущих требованиях к универсальной подготовки в волейболе.

Для достижения поставленной цели использованы следующие методы исследования: анализ, обобщение научной литературы по вопросам сущности базовых понятий профессиональной терминологии, систематизация упражнений для развития отдельных двигательных качеств в прочессе общей физической подготовки.

Ключевые слова: студенты, волейбол, физическое воспитание, двигательные качества.

\section{SUM MARY}

Borysenko Volodymyr, Kozeruk Yuliia, Hryb Tetiana, Klymenchenko Tetiana. Development of students' motor qualities during volleyball training in the process of physical education.

Volleyball today places high demands on players to develop their motor skills and functional capabilities. The game has many techniques of sudden movements, jumps, falls, and strokes. This requires comprehensive development of motor skills of students of higher education institutions.

General physical preparation in volleyball training covers a wide range of exercises that develop motor qualities in such a ratio that is necessary in this sport, which aims at versatile physical development, strengthening health, correcting the posture, enhancing the body's functional capabilities, expanding motor skills, development of motor skills (strength, speed, endurance, agility, flexibility), improving gameplay, competitive performance, stimulation of restorative processes in the body.

Development of motor skills is closely interrelated and mutually conditioned. Development of one of them has a certain effect on the development of others. In this case, the impact can be positive, neutral and negative, for example, if more attention is paid to the development of strength, then flexibility and mobility in the joints are lost. Therefore, the 
issue of the most appropriate development of motor qualities is of great importance. Optimal development of motor qualities occurs with their complex application.

Means of general physical training are all-round exercises aimed at motor skills development in the process of walking, running, jumping, throwing, as well as exercises on various projectiles, simulators, playing other sports.

Periodically under the developmental exercises are allocated individual classes. The share of general developmental exercises in classes at different stages and periods of the educational process is different. Depending on their tasks, they can be included in the preparatory part of the session, the main and final.

The purpose of the study is to make an attempt to systematize general physical training exercises that, in the complex, will serve as a base for volleyball training in the physical education process. This complex can be recommended for students of higher education institutions in the form of non-formal and informal education, which will help to solve the problem of increasing requirements for universal volleyball training

To achieve this goal, the following research methods were used: analysis, generalization of scientific literature on the essence of basic concepts of professional terminology, systematization of exercises for the development of individual motor qualities in the process of general physical training.

Key words: students, volleyball, physical education, motor qualities.

$$
\text { удк 371.315.6 }
$$

\section{Світлана Генкал}

Сумський державний педагогічний університет імені A.C. Макаренка ORCID ID 0000-0001-7812-6103

DOI 10.24139/2312-5993/2019.08/198-209

\section{ФУНДАМЕНТАЛІЗАЦІЯ БІОЛОГІЧНОЇ ПРОФІЛЬНОӦ ОСВІТИ ШЛЯХОМ УДОСКОНАЛЕННЯ ЗМІСТУ ІСТОРИКО-НАУКОВИМИ ЗНАННЯМИ}

у статті обгрунтовуються необхідність фрундаменталізації біологічної профрільної освіти шляхом збагачення змісту історико-науковими знаннями. Відзначається, що необхідність модернізації системи освіти ставить перед педагогічною наукою завдання вдосконалення не тільки процесуального, але й змістового компоненту навчання. Акцентується увага на тому, що фундаменталізація змісту освіти забезпечує формування ключових і предметних компетентностей, глибоких знань про будову, функції, еволюцію біологічних систем, надає можливість для творчої самореалізачії учнів. Розглядаються підходи, компоненти процесу фундаменталізації біологічної профрільної освіти в напрямі використання освітнього потенціалу знань із історії розвитку біологічної науки та особливості організації освітнього процесу.

Ключові слова: фундаменталізація, гуманітаризація, зміст освіти, профрільне навчання, принцип історизму, історико-наукові знання, природничо-наукова картина світу, світогляд.

Постановка проблеми. Входження України у світовий освітній простір зумовлює необхідність модернізації системи освіти та ставить перед педагогічною наукою завдання створення нових і вдосконалення 